NBER WORKING PAPER SERIES

\title{
OLIGOPOLY IN INTERNATIONAL TRADE: RISE, FALL AND RESURGENCE
}

\author{
Keith Head \\ Barbara J Spencer \\ Working Paper 23720 \\ http://www.nber.org/papers/w23720 \\ NATIONAL BUREAU OF ECONOMIC RESEARCH \\ 1050 Massachusetts Avenue \\ Cambridge, MA 02138 \\ August 2017
}

We are grateful to James A. Brander, J. David Richardson, Jacques Thisse and an anonymous referee for helpful comments. We also thank Vanessa Alviarez for assembling the data used in Figure 4 and Chenying Yang for the data for Figure 2. The views expressed herein are those of the authors and do not necessarily reflect the views of the National Bureau of Economic Research.

NBER working papers are circulated for discussion and comment purposes. They have not been peer-reviewed or been subject to the review by the NBER Board of Directors that accompanies official NBER publications.

(C) 2017 by Keith Head and Barbara J Spencer. All rights reserved. Short sections of text, not to exceed two paragraphs, may be quoted without explicit permission provided that full credit, including $(\odot$ notice, is given to the source. 
Oligopoly in International Trade: Rise, Fall and Resurgence

Keith Head and Barbara J Spencer

NBER Working Paper No. 23720

August 2017

JEL No. F12,F13,F14,L13

\begin{abstract}
$\underline{\text { ABSTRACT }}$
Large firms played a central role in the "new trade" models that became a major focus of trade economists in the early 1980s. Subsequent literature for the most part kept imperfect competition but jettisoned oligopoly. Instead, as the heterogeneous firms literature burgeoned in the 2000s, monopolistic competition quickly became established as the workhorse model. The use of oligopoly in trade models has been criticized for reasons that we argue are unpersuasive. Renewed incorporation of oligopolistic firms in international trade is warranted. Quantitative investigations of welfare effects of trade policy should again address the impact of such policies on the allocation of profits across countries.
\end{abstract}

\author{
Keith Head \\ University of British Columbia \\ Sauder School of Business \\ 2053 Main Mall \\ Vancouver, BC V6T 1Z2 \\ CANADA \\ and CEPR \\ keith.head@sauder.ubc.ca \\ Barbara J Spencer \\ University of British Columbia \\ Sauder School of Business \\ 2053 Main Mall \\ Vancouver, BC V6T 1Z2 \\ CANADA \\ and NBER \\ barbara.spencer@sauder.ubc.ca
}




\section{Introduction}

Oligopoly is pervasive in our daily lives. We fly on Airbuses or Boeings, propelled by engines made by General Electric, Pratt \& Whitney, or Rolls-Royce. Our phone calls are very likely made on Apple or Samsung handsets. From the beers we drink, to the appliances that wash our dishes or clothes, even to the food we give our pets, most people chose between products made by a small number of large firms. Yet oligopoly is rarely found in the models utilized in international trade. This was true before 1980 when models of perfect competition had a near monopoly on the field and it has been true in the last two decades when monopolistic competition has dominated. In the early 1980s oligopoly played a starring role in international trade models, in part because oligopoly provided the foundation of strategic trade policy. While that research continues to be cited and has inspired related work over many years, we show that the share of papers in the Journal of International Economics mentioning oligopoly has been declining since the early 1990s.

This paper considers the growth, relative decline, and resurgence of interest in theory and empirical work involving oligopoly and trade since its inception in 1981. Much of this research employs oligopoly to address the traditional questions of the patterns and gains from trade. The early papers on what came to be known as strategic trade policy are also a focus of our discussion. Our chief goals are to (1) draw attention to the continued importance of oligopoly in the global economy, (2) rebut some of the perceived defects of oligopoly models and their applications to strategic trade policy and (3) discuss a growing number of new papers utilizing a different set of oligopoly frameworks from those that featured in the earlier literature. The new approach allows for oligopoly structures to be deployed in quantitative analyses of trade with heterogeneous firms, potentially of massive size. We conclude that a well-justified revival of oligopoly is already under way. Although this paper is primarily a review, we also provide some new descriptive evidence showing many product markets in many countries are highly concentrated.

Section 2 introduces the early models of oligopoly and international trade and Section 3 documents the (relative) decline in the use of such models after the initial burst of interest in oligopoly in the 1980s. Section 4 sets out various possible justifications for the decline, together with counter 
arguments. Section 4 is organized under the following headings: "Is oligopoly empirically important?," "Do strategic trade policy predictions lack robustness?," "Are the political economy risks of strategic trade policy too large?," "Are the potential gains from strategic trade policy too small?," and "Is monopolistic competition better at handling heterogeneous firms?." Section 5 then demonstrates that a revival in the use of oligopoly models in international trade is under way and section 6 contains concluding remarks.

\section{Oligopoly arrives on the trade scene}

Prior to the 1980s, research on international trade was mostly based on Ricardian and HeckscherOhlin trade models, which rely on perfect competition as the underlying market structure. There was a role for industries, but no role for firms. In the 1970s, a few papers addressed the implications of monopoly for trade. Most notably, Melvin and Warne (1973) examine the gains from trade under monopoly and Katrak (1977) and Auquier and Caves (1979) consider commercial policy.

Although there was some early discussion of oligopoly and international trade (see Caves (1974)), formal analysis of oligopoly and trade began with the publication in February 1981 of of Brander (1981), "Intra-industry trade in identical commodities." The paper, based on James Brander's 1979 Ph.D. thesis, introduced the idea of segmented markets in a model in which a domestic and foreign firm set their outputs separately in each country under Cournot competition. The outcome was two-way trade in identical products..$^{1}$ Brander's referee on this paper was Paul Krugman. The two subsequently extended the work in Brander and Krugman (1983), "A 'reciprocal dumping' model of international trade." Also in 1981, James Markusen published "Trade and the gains from trade under imperfect competition," based on the traditional assumption of integrated markets, sometimes referred to as unified markets. Markusen (1981) shows that trade by a Cournot oligopoly increases world welfare, but that it is possible for a large country to lose. Another early contribution to trade and oligopoly is Krugman (1984), "Import Protection as Export

\footnotetext{
${ }^{1}$ Since marginal revenue for the first unit of exports is equal to price net of transport costs, exports are required to equalize marginal revenue in each country provided transport costs are not too high.
} 
Promotion: International Competition in the presence of oligopoly and economies of scale," which was presented at a 1982 conference in Geneva organized by Henryk Kierzkowski and published in the 1984 conference volume.

Spencer and Brander (1983), "Subsidies to R\&D and industrial strategy," and Brander and Spencer (1985), "Export subsidies and international market share rivalry," are the papers best known in the literature for developing the idea of strategic trade policy. In both papers a domestic and a foreign firm compete as Cournot duopolists in a third-country market. The 1983 paper was the first to consider the incentives for R\&D and export policy in a model of oligopolistic competition. The paper involves a three-stage game in which commitment to a subsidy or tax applied to R\&D and/or to exports can increase domestic welfare by influencing the subsequent game played between firms ${ }^{2}$ An R\&D subsidy makes it credible for the domestic firm to commit to a higher level of R\&D. As a result, the foreign firm reduces its $R \& D$ and exports and the profit of the domestic firm rises net of the subsidy. Brander and Spencer (1985) analyze a simpler two-stage game (referred to as the Brander-Spencer model) so as to emphasize the profit-shifting role of export subsidies in a more standard international trade setting in which a numeraire good is used to achieve trade balance.

Strategic trade policy examines the implications of trade or industrial policy when firms interact in an actual or potential international oligopoly. We define oligopoly here in the usual way as an industry characterized by a small number of firms who recognize that they are interdependent with respect to their pricing or output decisions. Bertrand and Cournot competition are typical examples of interdependence. If the strategic-trade policy definition were expanded to include the leader-follower model, then Brander and Spencer (1981) in the Canadian Journal of Economics is the first application of strategic trade policy. In that paper, a foreign monopoly chooses between entry deterrence based on the model of Dixit (1979) and Stackelberg leader-follower competition with a domestic firm. The domestic country can gain from an import tariff that shifts profits to the domestic economy by inducing domestic entry 3

\footnotetext{
${ }^{2}$ The basic model of simultaneous commitment to R\&D or investment is developed in Brander and Spencer (1983).

${ }^{3} \mathrm{~A}$ drawback of the paper is that the Dixit (1979) entry-deterrence model is not subgame perfect unless the incum-
} 
Import tariffs also feature in Brander and Spencer (1984a), presented at the 1982 Kierzkowski conference. The paper examines a profit-shifting import tariff under Cournot competition with a domestic and foreign firm and extends the analysis to the segmented markets model with intraindustry trade $\sqrt[4]{\text { Dixit }}$ (1984) considers trade policy allowing for general numbers of foreign and domestic firms in a similar setting. Again for Cournot competition, Venables (1985) examines the effects of trade policy and differences in endowments and technology for intra-industry trade under free entry. Eaton and Grossman (1986) use a conjectural variation framework to explore the implications of the mode of competition for the welfare effects of trade and industrial policies.

Figure 1: The enduring impact of some key oligopoly papers in trade

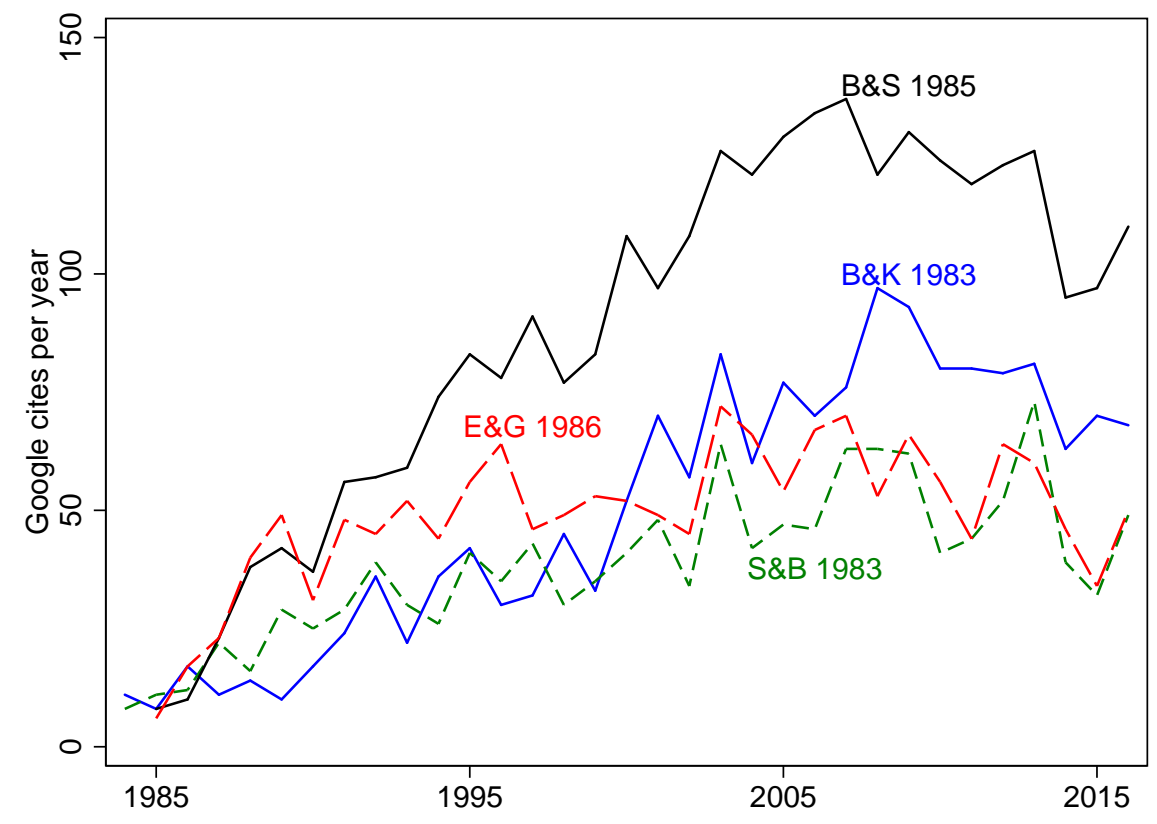

Figure 1 depicts annual citations for four seminal papers that gave a central role to oligopoly and trade: B\&K 1983 "A 'reciprocal dumping' model of international trade," S\&B 1983, "International R\&D rivalry and industrial strategy," B\&S 1985 "Export subsidies and international market share rivalry," and E\&G 1986 "Optimal trade and industrial policy under oligopoly." We see that citations to these papers rise for over two decades, peaking in the 63-137 range around 2007. bent firm can credibly commit to its output

${ }^{4}$ Brander and Spencer (1984b) explore the welfare effects of rent-extracting import tariffs under various market structures, including a foreign Cournot duopoly. 
Thereafter, citations decline somewhat but remain between 50 and 110 in 2016.

\section{The (relative) decline of oligopoly in trade}

When did oligopoly rise to prominence and when did it fall into relative decline? From the initial publications in the early 1980s, interest in oligopoly and trade intensified and the topic generated a significant literature over the next decade. Volume III of the Handbook of International Economics dedicated a full chapter, Brander (1995), to strategic trade policy. Oligopoly also featured importantly in the chapters on trade policy and regional integration. In contrast to the previous volume, volume IV of the Handbook, published in 2014, mentions oligopoly only in passing.

Figure 2: Papers mentioning oligopoly (or similar terms) as a share of all papers published in the Journal of International Economics

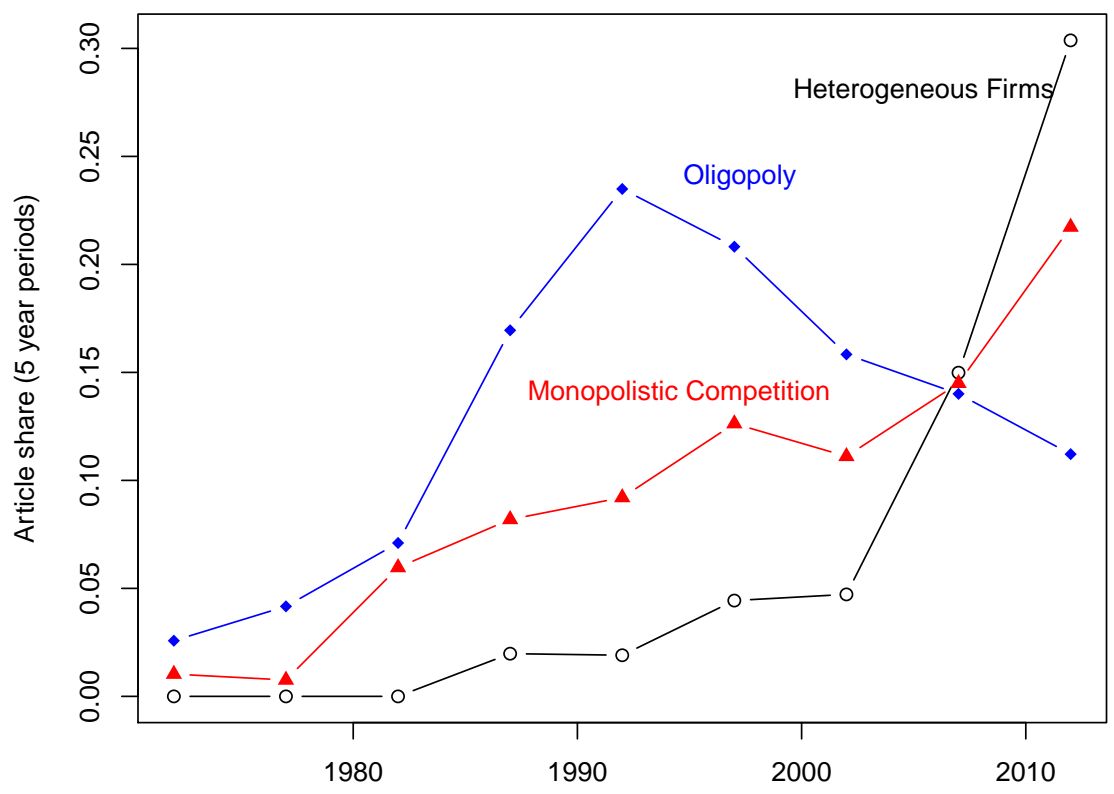

While the contents of the Handbooks are suggestive of a decline in trade economists' interest in oligopoly sometime after 1995, publication data offers a more precise picture of the temporal pattern. We used the Elsevier search engine to search the text of every paper published in the top field journal, the Journal of International Economics (JIE), for the use of the term oligopoly. 
Since exact phrasing differs from paper to paper, we included related words such as oligopolistic, duopoly, rent-extracting," "profit shifting," and "strategic trade policy." For comparison we also searched for papers using the term "monopolistic competition." Finally to corroborate one of the hypotheses we had for the decline of oligopoly, we searched for papers mentioning "heterogeneous firms." The categories are not mutually exclusive since many of the papers incorporating "heterogeneous firms", also assume monopolistic competition. Since the number of papers published each year in the JIE has risen, we normalize by that total to show shares of papers. To facilitate data collection and focus on the main trends, we pool citations over five-year periods.

Figure 2 shows that oligopoly-related terms surged in papers published in the JIE in the 1980s, with the share peaking sometime in the early 1990s. Use of "monopolistic competition" rises steadily, exceeding oligopoly in about 2008. Around the same time, heterogeneous firms papers shoot up, passing both of the other categories. Despite the relative decline in mentions of oligopoly by the late 1990s, yearly citations to the seminal papers in Figure 1 increase until 2007 and do not fall much after that. It would be a mistake to conclude that interest in the topic ever disappeared.

\section{Why did oligopoly fall out of favour?}

Why did oligopoly, which was of such great interest to trade economists in the 1980s, decline in relative importance? There are many possible explanations including just swings in intellectual fashion. We focus on the following set of perceived drawbacks to the use of oligopoly and trade models that may have contributed to the decline. Since we find significant faults with each critique, we express them in the form of questions.

1. Is oligopoly empirically important in the current global economy?

2. Do strategic trade policy predictions lack robustness?

3. Are the political economy risks of strategic trade policy too large?

4. Are the potential gains from strategic trade policy too small?

5. Is monopolistic competition better at handling heterogeneous firms than oligopoly? 
The second, third, and fourth critiques are not attacks on the oligopoly assumption per se but rather on its application in papers on strategic trade policy. However, the exciting (or heretical, depending on the perspective) predictions of this literature accounted for a large part of the motivation for considering oligopoly in trade. We consider each of the five perceived drawbacks of oligopoly in the following subsections.

\subsection{Is oligopoly empirically important?}

One reservation about the relevance of oligopoly models in trade is the view that they only apply in a handful of industries, with the most recognized example being large commercial aircraft. In this subsection we assemble evidence from a variety of different sources to illustrate the prevalence of competition dominated by a few large firms. A natural starting point is the concentration of US manufacturing industries. Figure 3 shows the distribution of the 4-firm concentration ratio (CR4) across 364 6-digit industries in 2012. It shows that the most common CR4 is in the 20-30\% range. However, more than half of all manufacturing output occurs in industries with a CR4 over $46 \%$ and there are 76 industries where the top four firms control more than $60 \%$ of the market, the threshold Shepherd (1982) uses for "tight oligopoly." Table 1 lists the 15 most concentrated industries in the US as measured by the CR4. The products are diverse and include industries that have billions of dollars in sales.

Trade in manufactures appears to be even more dominated by large firms than manufacturing production. Freund and Pierola (2015) report that the top five firms account for $30 \%$ of aggregate exports on average across the 32 countries they study. Hence the market shares within industries must be substantially larger than at the industry level. Gaubert and Itskhoki (2016) find that the largest firm in a typical French manufacturing industry has a market share of $20 \%$ - despite the median industry comprising over 200 firms. The prevalence of export superstars is in line with the extra fixed costs of reaching foreign markets stipulated by the Melitz (2003) model.

There is evidence that markets are becoming more concentrated over time. Autor et al. (2017a) report increases in 4-firm concentration ratios from 1982 to 2012 in time-consistent industries 
Figure 3: Most industries are not highly concentrated but there is a substantial right tail

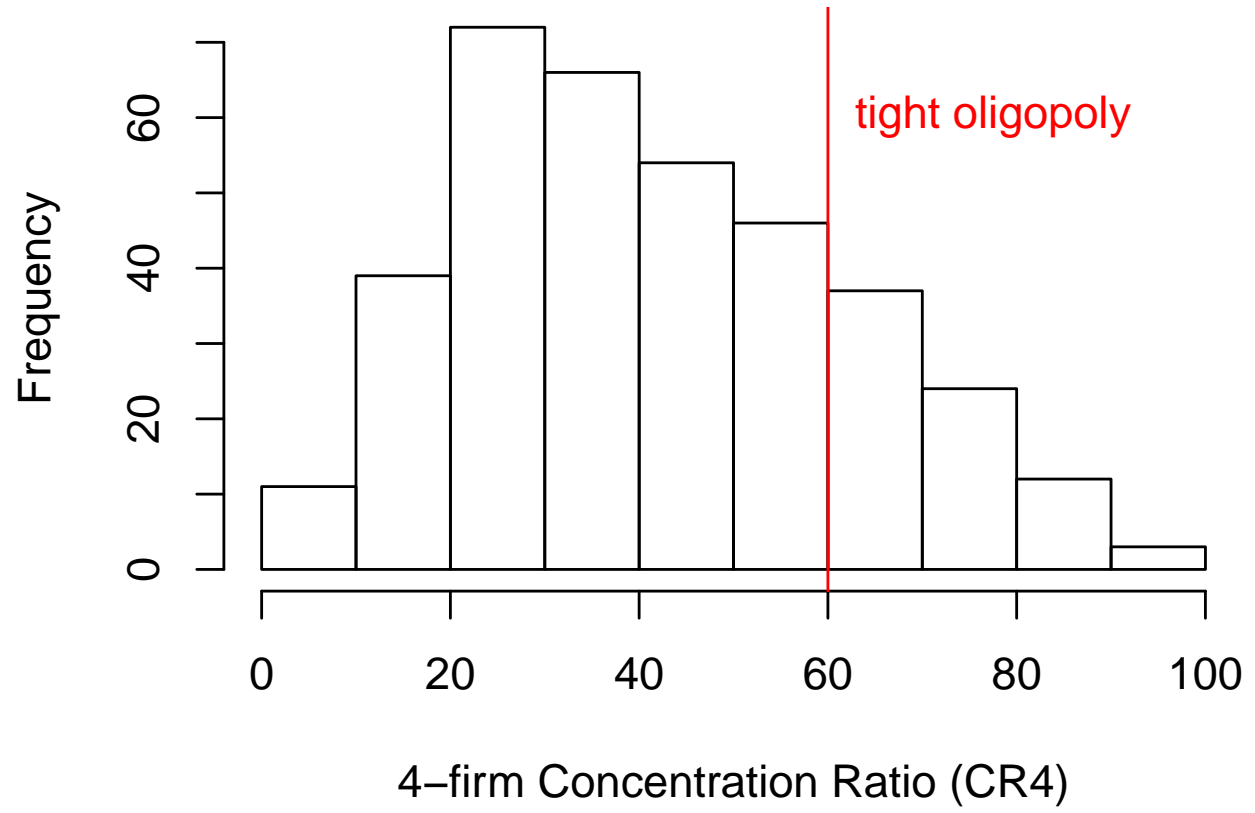

(based on 1987 4-digit SIC) in all six major sectors of the US economy. Some of the biggest increases occur in non-traded sectors such as retail and wholesale trade and utilities and services. In finance (a tradeable service), concentration rises from $24 \%$ to $35 \%$ and in manufacturing it rises from $38 \%$ to $43 \%$.

A companion paper, Autor et al. (2017b), argues that concentration has risen across many industries due to a "shift in competitive conditions" which the paper models as an exogenous increase in the price elasticity of demand. An increase in price elasticity disproportionately magnifies the sales of firms with lower marginal costs (referred to as superstars). Since these firms were larger to start out with, concentration rises. Furthermore, the superstar firms have lower labour shares because of the assumption that all firms have the same fixed cost of overhead labour. Thus, the reallocation of demand towards superstars can give rise to an overall reduction in the labour share. An unattractive feature of this model is that the superstar firms do not interact with each other, something that could be remedied through the use of an oligopoly market structure. This would allow markups to adjust endogenously to changes in demand elasticity as well as other determinants 
Table 1: Industries where the top 4 firms account for more than $80 \%$ of sales (2012 data)

\section{Industry name}

Household laundry equipment manufacturing

Guided missile and space vehicle manufacturing

Household refrigerator and home freezer manufacturing

Guided missile and space vehicle propulsion units

Tobacco manufacturing

Breweries

Primary battery manufacturing

Wet corn milling

Glass container manufacturing

Phosphatic fertilizer manufacturing

Small arms ammunition manufacturing

Electric lamp bulb and part manufacturing

Military armored vehicle, tank, and tank component manufacturing

Light truck and utility vehicle manufacturing

Aircraft manufacturing
CR4 Sales (\$bn)

100

3.4

93.3

19.7

92.9

3.5

88.5

4.2

87.8

40.2

87.8

28.4

87.2

86.4

4.4

86.3

13.0

85.3

84.2

83.7

11.6

3.6

1.9

83.7

5.6

80.8

122.2

80.1

of market conditions such as the number of firms in the industry.

The numbers shown in Figure 3 and Table 1 have the potential to misstate the importance of oligopoly in the US market. This is because they show concentration of revenue among firms covered by the US economic census, which excludes effects on concentration arising from the US sales of foreign firms that export to the US. Autor et al.(2017a) attempt to adjust for this by treating imports from each major country group as if they were sold in the US market by a single firm. This method will overstate concentration in industries where country groups have multiple firms in the major export industries. For example the group comprising Germany, Japan, and rest of the world has more than 10 sizeable car makers. On the other hand, the presence of multinationals that source from multiple countries, such as Nike, could bias this import correction into understating concentration.

To address the above concern about US Census-based concentration indexes, we have used data on company market shares by country for a range of consumer goods from Euromonitor International. The data are calculated without regard to the location of production so imported goods are included. Figure 4 shows trends in the combined market shares of the four biggest firms producing 9 products in 46-79 countries. We use the median country to dampen the influence of 
Figure 4: Trends in dominance of top 4 firms (median 4-firm concentration ratios taken over the number of country-markets shown in parentheses)

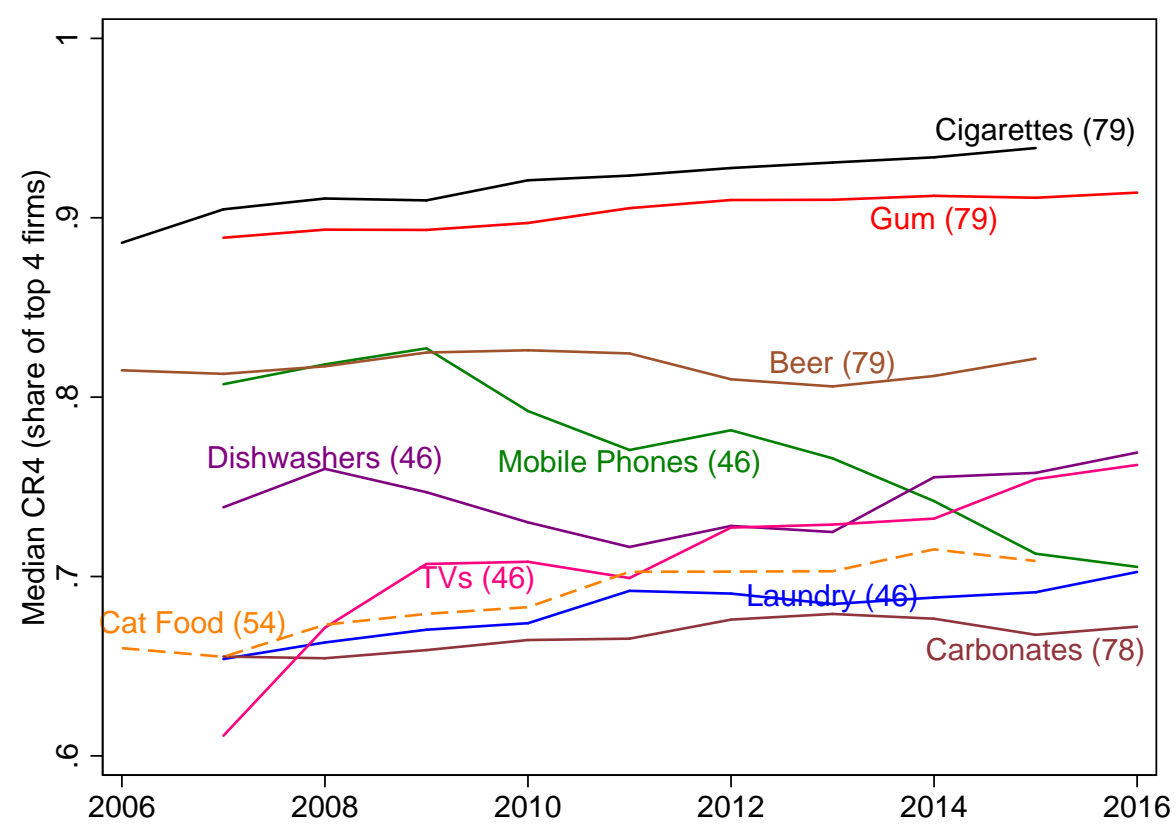

outliers. The products are selected partly based on Table 1 and partly on the familiar products mentioned in our opening paragraph. The figure underscores the dominance of the few. In over half of the 79 markets where cigarette sales are tracked by brand, the top 4 firms cumulatively account for over $90 \%$ of the sales. Cigarettes are infamous as an oligopoly; it is more surprising to see similar market dominance in chewing gum. For all products shown, the top 4 firms account for over $2 / 3$ of sales in the median county. Despite rises in trade and multinational investment, concentration is either stable or trending up. One exception, mobile phones, is explained by the dramatic decline in the fortunes of Nokia over this period. Also, since this data set measures market shares for mobile phones in numbers, rather than values, the market shares of Apple and Samsung based on high-priced phones are understated.

Rising concentration drew the attention of Obama administration economists. The Council of Economic Advisers (2016a) traces a link from rising concentration (9 out of 12 large sectors listed in the report's Table 1-2 show increases in the shares of the top 50 firms), to the increasing share 
of profits in national income, and then to rising inequality of wealth and income.

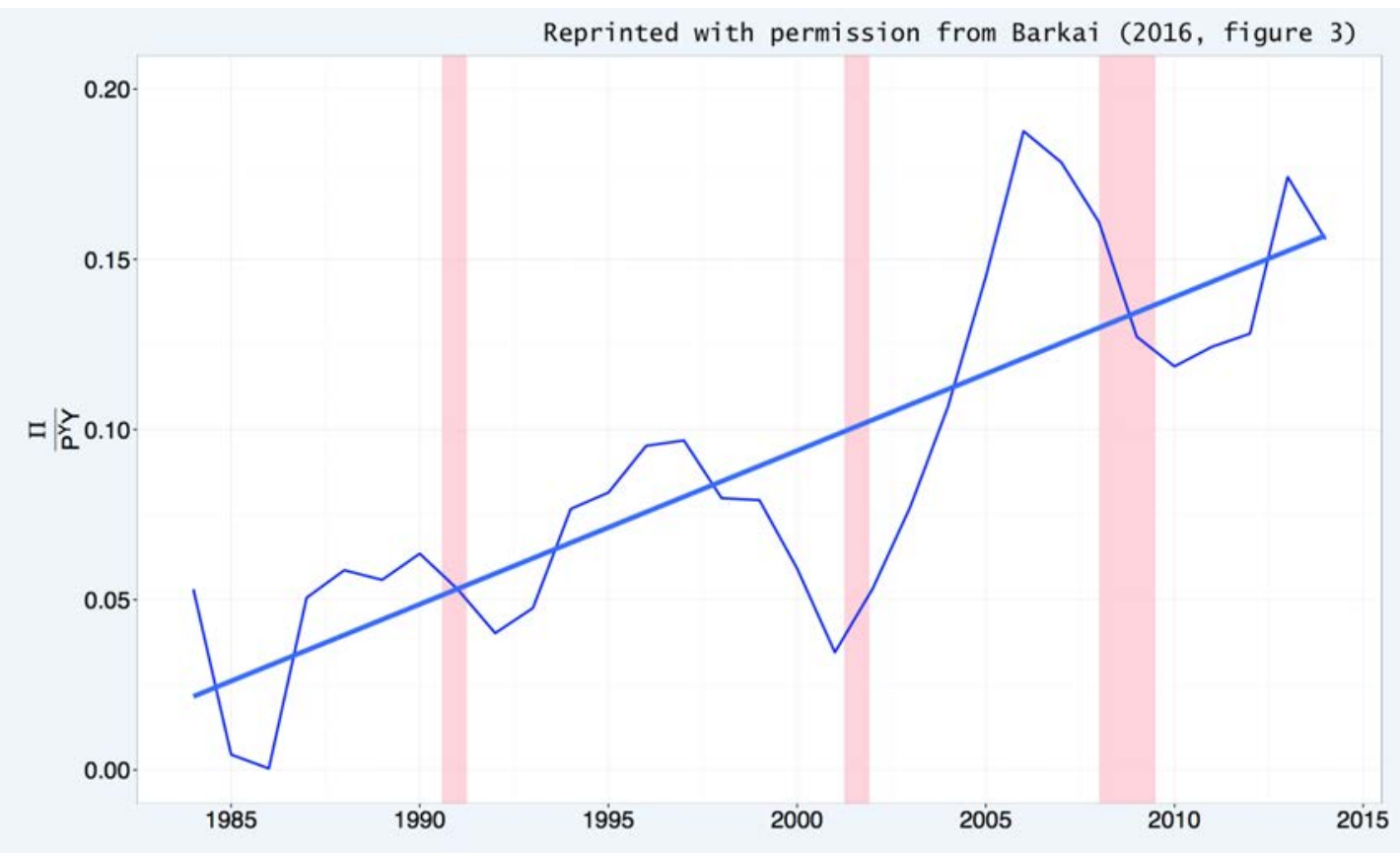

Figure 5: The rising share of profits in GDP

Barkai (2016) separates profits from capital income, with the former being defined as returns to owners above and beyond the opportunity cost of capital. He finds that both labour and capital shares of US GDP have been declining over the last decades. Through the lens of general equilibrium model, Barkai argues that only an increase in markups can explain the simultaneous fall in both labour and capital shares. This result accords well with observed rises in CR4s. As illustrated in Figure 5, we reprint (with permission) Barkai's calculations showing profit shares tripling from below $5 \%$ in the early 1980 s to $15 \%$ in the most recent data.

In summary, oligopoly is a robust characteristic of a broad set of industries in the US and around the world. Concentration of sales among the four largest firms is trending up across a wide variety of industries. As has been noted, these trends might help to explain rising inequality and falling labour shares of national income. While it is certainly possible to explain rising concentration and profit shares in a monopolistic competition model, the assumption of "massless" firms does not accord with the data. Many industries are dominated worldwide by a few massive firms. 
Furthermore, the free-entry assumption made in most monopolistic competition models is hard to reconcile with the observation of large and rising profits. We return to these themes later in this paper but now address the critiques of oligopoly and strategic trade policy that were based on theory rather than empirical observation.

\subsection{Do strategic trade policy predictions lack robustness?}

The rise of oligopoly models in international trade theory carried with it the use of game theory and other insights from industrial organization. The specific application to international trade also introduced two novel features: first, that oligopolistic firms would treat markets in each country as segmented rather than integrated and the second, that countries had a motive to raise domestic welfare by shifting rents from foreign firms to the domestic economy in the form of higher domestic profits, increased government revenue or above-normal wages. Since the game played by firms in an oligopoly can be modelled in a number of ways, resulting in different trade-policy prescriptions, models of oligopoly and trade incorporating one or both of the above two features soon found opposition in the literature as giving contradictory guidance for policy.

This section addresses the claim that due to lack of robustness with respect to the mode of competition, whether Cournot or Bertrand, strategic trade policies cannot be successfully applied in practice. Some criticisms with respect to other modelling assumptions are also addressed.

It matters for the analysis whether the market in just one country is affected by the particular trade policy--the foreign country for export policy and the domestic country for import policy-or whether there are linkages between markets causing trade policy to impact sales by oligopolistic firms in both domestic and export markets. Most papers focus on the main implications of strategic trade policy by considering only one market. The segmented markets model of Brander (1981) and Brander and Krugman (1983) provides a useful setting for consideration of strategic trade policy. The model emphasizes the importance of intra-industry trade, but if marginal costs are constant and the numbers of firms in each country are fixed, the effects of trade policy are again restricted to one market: an export subsidy affects sales of oligopolistic firms only in the foreign market and an 
import tariff affects sales only at home. However, if markets are integrated rather than segmented, or if they are segmented, but with linkages created by variable marginal costs or free entry, then the interactions between markets need to be taken into account.

In Subsection 4.2.1 we consider the robustness of strategic trade policy with respect to Cournot versus Bertrand competition for the case in which there is no interaction between the foreign and domestic markets. The analysis encompasses results from the Brander-Krugman segmented markets model when marginal costs are constant and there is no entry or exit. Consideration is given to import tariffs in addition to the export promotion policies that have been the main focus of criticism. In Subsection 4.2.2, we consider the implications of two sets of modelling assumptions that create linkages between markets: namely, integrated versus segmented markets and free entry.

\subsubsection{Cournot vs. Bertrand: No interaction between markets}

The potential gains from subsidizing the exports of domestic firms engaged in oligopolistic competition with foreign firms are generally not perceived as robust to small plausible changes in assumptions. An early and highly influential criticism of strategic trade policy was the demonstration by Eaton and Grossman (1986) that strategic trade policy applied directly to exports is sensitive to the form of oligopolistic interaction. Specifically, if there is Bertrand rather than Cournot competition between a domestic and foreign firm, an export tax rather than an export subsidy raises domestic welfare under most demand conditions. With Cournot behaviour, a commitment to an export subsidy raises the market share and profit of the domestic firm because the foreign firm responds by reducing its output. There is a domestic welfare gain since the profit of the domestic firm increases by more than the cost of the subsidy (see Brander and Spencer (1985)). By contrast, with Bertrand behaviour, a commitment to a domestic export tax causes the foreign firm to raise its price. The domestic country benefits from the higher profits inclusive of tax revenue associated with the softening of foreign competition.

Since the nature of competition may not be known in any particular industry, the dependence of the sign of export policy on market structure was commonly viewed as severely damaging to 
the relevance of strategic trade policy for actual policy decisions. However, this criticism becomes less important to the extent that R\&D subsidies applied to export oriented industries are both more practical and more robust as strategic trade policy instruments. A significant barrier limiting the use of export subsidies, but not R\&D subsidies, is that they are prohibited under GATT (the General Agreement on Tariffs and Trade) 5 Bagwell and Staiger (1994) provide support for the robustness of R\&D policy as a strategic trade policy. Taking into account the uncertainty of R\&D outcomes, the paper shows that if a domestic and foreign firm are engaged in either Bertrand or Cournot competition, a domestic R\&D subsidy shifts profits from the foreign firm to the domestic country, raising domestic welfare.

Maggi (1996) develops a model of capacity-price competition to re-examine the sensitivity of strategic trade policy to the mode of oligopolistic competition. Firms are modelled as committing to capacity before setting prices, but production can be expanded above "capacity" at an additional marginal cost, which represents the magnitude of the capacity constraint. The equilibrium outcome ranges from Bertrand to Cournot as the capacity constraint becomes larger. A main point of the paper is that a subsidy to capacity can be an attractive policy even if the government knows nothing about the mode of competition ${ }^{6}$ Supposing a domestic and foreign firm export to a third country market, Maggi (1996) shows that the appropriate strategic trade policy applied directly to exports remains sensitive to the mode of competition. For low values of the capacity constraint, an export tax raises domestic welfare, but the optimal policy switches to a subsidy as the capacity constraint gets larger and the equilibrium outcome becomes more similar to the outcome in a one shot Cournot game. By contrast, a small subsidy to capacity (weakly) increases domestic welfare regardless of the mode of competition. The gain is strictly positive if the capacity constraint is sufficiently large.

Whether an export subsidy or tax is the appropriate strategic trade policy is also affected by the relative number of domestic and foreign firms. As shown by Dixit (1984), an export subsidy

\footnotetext{
${ }^{5}$ Despite demonstrating that an export subsidy is more efficient than an R\&D subsidy as a profit-shifting device, Spencer and Brander (1983) chose to focus on R\&D subsidies. In addition to the GATT prohibition, the importance of MITI policies in Japan at the time, made the implications of R\&D subsidies applied to export-oriented industries of particular policy relevance. See, for example, Hufbauer and Erb (1984, pp. 107-108).

${ }^{6}$ Subsidies to capacity would include both direct and indirect subsidies to new plant and equipment or to R\&D that makes plant and equipment more productive. Indirect subsidies include low-interest loans or tax credits.
} 
raises welfare only if the number of domestic firms is not too large relative to the number of foreign firms..$^{7}$ Similarly, the optimal R\&D policy in Bagwell and Staiger (1994) can switch from a subsidy to a tax with an increase in the relative number of domestic to foreign firms, but presumably the relative size of the foreign and domestic industries is something that can be more readily observed than the mode of firm behaviour.

A further criticism of the 1985 Brander-Spencer model is that it ignores general equilibrium effects of trade policy on factor prices. Dixit and Grossman (1986) show that the effect of export subsidies in pushing up the cost of a scarce factor, such as engineers, reduces the potential gain from an export subsidy but the gain nevertheless remains positive. One reason for the recent resurgence of interest in oligopoly and trade is the development of models that address important aspects of general equilibrium while including sectors with oligopoly. That said, strategic trade policy is fundamentally directed at individual industries, not the whole economy. General equilibrium effects are likely to be less important when a policy is applied to only a few industries than to all imports or all exports.

Now turning to a brief consideration of import tariffs, there are some exceptions, but the contention that the domestic country gains from an import tariff (rather than an import subsidy) with segmented markets seems robust. Brander and Spencer (1984a) show that the optimal import tariff for a Cournot duopoly producing a homogeneous good with one domestic and one foreign firm is strictly positive under broad demand conditions. Markusen and Venables (1988), Cheng (1988) and Clarke and Collie (2006) show that the domestic gain from an import tariff extends to a broader range of settings. For segmented markets with differentiated products, Leahy and Neary (2015) show that in moving from autarky to free trade, the pattern of effects of an import tariff on welfare tends not to be sensitive to the choice of Bertrand or Cournot competition.

In summary, the "informational" critique of Eaton and Grossman (1986) is not as relevant as a bar to the practical application of strategic trade policy towards exports as it originally seemed. Policies applied directly to exports are sensitive to the mode of competition, but as shown by

\footnotetext{
${ }^{7}$ For linear demand and the same marginal costs, an export subsidy raises domestic welfare if $n<N+1$ where $n$ and $N$ are respectively the number of domestic and foreign firms.
} 
Bagwell and Staiger (1994) and Maggi (1996), this criticism does not apply to subsidies to R\&D or capacity provided that the number of domestic firms is not too large. Fundamentally, oligopolies exist because of entry barriers such as a high cost of plant and equipment. As Harris (1989) states, "The simplest and most credible way of intervening in these types of industries is for the government to target its policies at those features of the industry that give rise to the oligopolistic nature of the industry in the first place-large sunk costs".

\subsubsection{Integrated vs. segmented markets and free entry}

The idea of segmented markets introduced by Brander (1981) and extended by Brander and Krugman (1983) helped explain the prevalence of two-way trade or cross-hauling between developed countries. If markets are segmented, each firm sets its choice variable determined by the mode of oligopolistic behaviour, quantity for Cournot and price for Bertrand, in each country separately. Due to limitations on arbitrage, prices can differ across countries by more than transport and other trade costs, such as tariffs. The alternative is the traditional assumption, familiar from models of perfect competition and trade, that markets are integrated. Under Cournot competition with integrated markets, each firm makes its entire production available to the world market without specifying a particular destination. Goods are allocated across countries by arbitrage with the result that market-clearing prices vary across countries only due to trade costs such as transport costs and tariffs. With integrated markets and Bertrand competition, each firm sets a wholesale price (not including trade costs) that would apply throughout the integrated market.

The segmented markets model faced some initial criticism. Arbitrage has appeal as a natural mechanism to enforce the integration of markets, and Ben-Zvi and Helpman (1992) express concern that the no-arbitrage assumption required for segmented markets might not be justified. Other

criticisms by Ben-Zvi and Helpman (1992) and Venables (1990) were more about the best way to model oligopoly than criticisms of the idea of segmented markets per se. Both papers incorporate the Kreps and Scheinkman (1983) model of capacity commitment, which they view as a better way 
of handling oligopolistic interaction than the standard Cournot and Bertrand models.$^{8}$

Markusen and Venables (1988) compare trade policy under integrated and segmented markets with Cournot competition and general numbers of domestic and foreign firms. For an integrated market with fixed numbers of firms, they show that a small import tariff unambiguously raises domestic welfare, but the welfare effect of a small export subsidy is ambiguous. In the latter case, domestic exports expand causing the price of the foreign good to fall, which improves the import terms of trade, but this benefit is at least partially offset by the cost of the subsidy to taxpayers. Arbitrage can bring special problems of its own. As Collie (1998) and Collie et al. (1999) point out, if all goods are homogeneous, an export subsidy as a sole policy will lower the foreign price, giving arbitragers a continual incentive to buy the product in the foreign country for export back to the domestic country.9

For integrated markets and Cournot competition with free entry, Horstmann and Markusen (1986) argue that an ad-valorem export or production subsidy will reduce welfare under a broad range of demand conditions. Domestic entry causes domestic firms to move up their average cost curves and a zero profit assumption rules out profit-shifting. Import tariffs have no effect on output per firm, so a tariff is not justified except perhaps for the usual terms of trade reasons. If instead markets are segmented and products are homogeneous with linear demand, Venables (1985) shows that both a small export subsidy and import tariff increase domestic welfare under Cournot competition with free entry. In response to a tariff, domestic firms move down their average cost curves.10

Head and Ries (1999) use variation in tariffs caused by the 1988 Canada-US free trade agreement to discriminate between these different predicted scale effects. They find that reductions in

\footnotetext{
${ }_{8}$ Venables (1990) argues that it would be reasonable to assume that capacity is set on a world-wide basis followed by price or quantity competition based on segmented markets.

${ }^{9}$ To avoid problems of existence of equilibrium when markets are integrated, Collie (1998) and Collie et al. (1999) argue that for a Cournot duopoly with homogeneous products, the appropriate policy is a combined trade policy instrument consisting of an export subsidy and an equal import tariff.

10 Ross (1988) shows that an import tariff has an ambiguous effect on output per firm when a domestic oligopoly, including a Cournot oligopoly, competes with imports from a competitive fringe under free entry. As Harris (1989) points out, the output at which perceived demand is tangent to the average cost curve is dependent on models, parameter values and functional forms.
} 
Canadian tariffs reduce output per plant, consistent with the prediction of Venables (1985). Reductions in US tariffs-equivalent from the firm's perspective to higher export subsidies—lead to increases in domestic production per plant. With economies of scale, this should move firms down their average cost curves, in contrast to the Horstmann and Markusen (1986) prediction.

When modelling free entry, the approach has been to assume that firms enter or exit in sufficient numbers in each country to force profits to zero. Although it is a useful theoretical exercise to examine the implications of small or atomistic firms engaged in strategic behaviour, the very word "oligopoly" derives from the Greek word oligo for few. When there are significant economies of scale (including fixed costs that are large relative to the size of the market) a few existing firms may earn above-normal profits, yet a lumpy entrant would make negative profits. This is sometimes dismissed as an "integer problem" but we believe it has substantial empirical relevance in many industries. With lumpy firms, small tariffs or subsidies may have not cause entry or exit and the strategic trade policy results for fixed numbers of firms would apply. 11

The suitability of the assumption of integrated markets for the analysis of international trade and oligopoly is called into question by the convincing evidence that many oligopolistic firms engage in price discrimination across countries (see for example, Atkeson and Burstein (2008)). Oligopolies are generally characterized by large firms that typically control the distribution channels for their goods. Contracts with wholesalers and retailers often include conditions that severely restrict sales to buyers in other countries, largely preventing arbitrage. For example, consumers are discouraged from cross border purchases of a wide variety of goods due to warranties that apply only in the country of purchase. With respect to high value items, such as automobiles, retail outlets in the United States may be prohibited by contract from selling to non-residents of the United States, such as Canadians. Burstein et al. (2003) documents that the costs of distribution represent more than $40 \%$ of the retail price of consumer goods in the United States and can vary significantly across countries ${ }^{12}$ Since distribution services are intensive in local labour and land, they are not

\footnotetext{
11 Eaton and Grossman (1986) point out that free entry does not remove incentives for profit shifting if firms are large or if infra-marginal firms make positive profits.

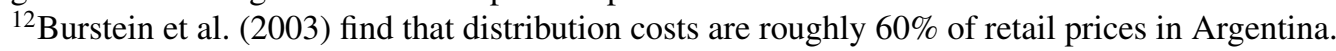


subject to international arbitrage. The control that large firms have over their distribution channels provides a natural support for international price discrimination and the assumption of segmented markets.

\subsection{Are the political economy risks of strategic trade policy too large?}

Krugman (1989) argues that the attention received by strategic trade policy "has been driven by forces beyond the idea's intellectual importance. The simple fact is that there is a huge external market for challenges to the orthodoxy of free trade. Any intellectually respectable case for interventionist trade policies, however honestly proposed - and the honesty of Brander and Spencer is not in question-will quickly find support for the wrong reasons." There is no doubt that some subsequent criticisms directed at the Brander-Spencer model were motivated by fear that the model would help justify trade policy targeted at specific industries ${ }^{13}$ Indeed, when early versions of strategic trade policy were presented at the National Bureau of Economic Research (NBER), a prominent member of the group expressed his strong opinion that this research "should be banned." As Stegemann (1989) points out: "The policy implications of models of strategic trade policy-taken at face value-were indeed disturbing. Suddenly, mainstream economists, using the latest tools of the trade, appeared to justify an 'activist' trade policy or an 'activist' industrial policy; suddenly, modes of intervention that had always been denounced by mainstream economists as 'protectionist' or 'mercantilist' policies were shown to enhance national welfare (rather than merely serving the interests of particular domestic groups at the expense of others)."

At first glance, political economy concerns seemed warranted by events in the 1980s. There was a belief in the US Congress that foreign governments were engaged in unfair export promotion and other trade practices that were hurting US industry, such as autos, steel and semiconductors. By the mid-1980s, lobbyists to the US Congress from a number of industries and unions were interested to learn about the ideas from the then recent research on strategic trade policy. For

\footnotetext{
${ }^{13}$ Spencer (1986), "What should trade policy target?," sets out the implications of the Brander-Spencer model for the features of industries where there may be a potential domestic gain from targeting.
} 
example, in 1984, major corporate and trade organizations sponsored a conference on the topic in Washington DC. The conference, commemorating the fiftieth anniversary of the Export-Import Bank of the United States, brought together academic economists with government officials and representatives of businesses and unions. Further publicity for strategic trade policy was provided by Nasar (1985) in Fortune Magazine ${ }^{14}$

One should not exaggerate the influence that strategic trade policy research had on actual policy making. The US government implemented policies benefiting autos (1981 VERs), steel (quotas from 1969-74) and semiconductors before the relevant research had been published.15 Indeed, governments took actions that could be described as strategic trade policy centuries before the theory had been developed. According to Irwin (1991), "Mercantilism as Strategic Trade Policy: The Anglo-Dutch Rivalry for the East India Trade", data from around 1620 AD shows that the Dutch were successful in shifting profit from the English by achieving a Stackelberg leadership position with respect to the East India trade. ${ }^{16}$

Other than the exception due to the ability of large countries to influence the terms of trade, the reliance on the assumption of perfect competition in the past led many traditional economists to argue for free trade, and even for unilateral free trade, regardless of foreign trade barriers. Such arguments appeared totally out of contact with the real world to most people in industries facing major pressures from international competition. The argument based on perfect competition that foreign export subsidies were simply misguided policies that hurt taxpayers in exporting countries to the long-run benefit of consumers in importing countries made economists seem particularly out of touch with reality.

The main message from strategic trade models is not that the theory promotes an "activist" trade policy targeting specific industries and firms for export promotion or import protection. Even if such policies would have the predicted effect, the theory emphases that domestic gains are mostly at the expense of firms and workers in other countries. As has been understood since Spencer and \begin{tabular}{l}
\hline${ }^{14}$ Sylvia Nasar later wrote a book about John Nash, A Beautiful Mind, which led to an Oscar-winning movie. \\
\hline${ }^{15}$ See Baldwin and Richardson (1987) for details of US trade policy from 1940 to the late 1980s. \\
${ }^{10}$ Irwin (1991) makes it clear that strategic trade policy is not related to the traditional mercantilist view that trade \\
is a zero-sum game in which only exports matter.
\end{tabular} 
Brander (1983), it is possible that foreign governments may choose to undertake similar actions leading to a prisoner's dilemma outcome in which the domestic and foreign countries are worse off. Instead, the main message is that economists now have something relevant to say about the motives for trade-policy actions taken by various governments and their implications for trading partners. The increasing dominance of trade by large oligopolistic firms (see section 4.1) underscores the importance of documenting the profits gained from trade and the profit-shifting implications of particular trade policies. Far from creating political economy risks, a much improved understanding of the incentives driving targeted policies and the magnitude of profit-shifting effects, would put the economics profession in a better position to help design trade agreements to prevent the use of beggar-thy-neighbour policies. As explained in the next section, the prevalence of oligopoly and the tendency for profits to be persistent and not quickly dissipated by entry means that the profit-shifting motive for trade policy is here to stay.

\subsection{Are the potential gains from strategic trade policy too small?}

Fear of the political risks led trade economists to impose a high bar for the potential welfare gains before seriously considering the implementation of strategic trade policy. Early efforts to quantify how such policies might work out in practice made it look like they offered paltry benefits at best. For example, in their chapter on quantification, Helpman and Krugman (1989, p. 178) concluded

"[T]he gains from such policy are small. Nothing in the quantitative analysis to date provides a justification for sweeping claims that imperfect markets offer large gains to sophisticated intervention, still less that neo-mercantilist policies can be the key to rapid economic growth. If there are really large benefits from trade intervention, they must lie in sources other than imperfect competition alone."

Venables (1994) conducts a systematic analysis of calibrating parameters for nine industries using data from five European countries. He considers a variety of different formulations of the oligopoly model. While upholding the prior conclusion that welfare gains tend to be small-at most $2.5 \%$ 
of base consumption-Venables provides several additional insights. First, he finds large quantity effects of the policies on trade flows. Second, he finds that higher welfare gains from export subsidies are associated with more concentrated industries. This is important since Venables measures concentration at the level of fairly aggregated industries and thus likely underestimates concentration in the relevant product markets. For example, "Electric motors, generators, etc." has a Herfindahl of just 0.02 , equivalent to an industry comprising 50 equal-sized firms.

A related question explored around the same time was how imperfect competition affected the gains from trade liberalization. Richardson (1989) surveyed early computable general equilibrium studies and found that welfare gains "are usually two to three times the size of those estimated in traditional frameworks with perfect competition." The most prominent paper considered by Richardson was Cox and Harris (1985), which found Canada could increase its GNP by 8-10\% via trade liberalization. The main source of these gains arises from limit pricing by domestic firms. Following tariff cuts, prices fall as the non-exiting firms realize economies of scale.

Feenstra (1995) argues for greater use of estimation rather than "calculation" (calibration of stylized models) in assessing the merits of strategic trade policy. Nevertheless, his bottom line is that "Like Krugman we will conclude there is little support for national gains due to strategic trade policies." Feenstra (1995) focuses on an early version of the Berry et al. (1999) analysis of Japan's 1981 voluntary export restraints (VER) in the automobile industry. The "bottom line" of that study is that the VER generated small welfare losses in the United States. Looking at the Berry et al. (1999) in greater detail, we see that the VER had large, but offsetting, impacts on US consumers and car makers from the US and Japan.

The first effect of the VER was to increase the pure profits of U.S. firms by about [21.3] billion dollars. It is hard to evaluate the magnitude of this figure. To put it into some perspective, though, our estimates imply that the pure profits (not including fixed costs) from Japanese automobile sales in the U.S. in 1990 were about [15.9] billion dollars, while the profits of U.S. firms in 1990 were about [\$48.2] billion. It seems that the profit-shifting effects of the VERs was not negligible. On the other hand, the burden 
placed on U.S. consumers was not negligible either as the compensating variation of the VERs was just over [\$27.3] billion. (italics added, amounts re-expressed in 2016 USD in [])

Profit increases were of the same order of magnitude as consumer surplus reductions and Berry et al. (1999) acknowledge that their analysis did not account for rents accruing to US auto workers. The large impact on profits suggests that it is imperative to include rents to firms and workers in welfare calculations involving oligopolistic industries. Indeed, when Berry et al. (1999) consider the counterfactual policy of a equivalent tariff on imported Japanese cars, they estimate it would have generated \$23bn in revenues, enough to create a welfare gain of \$17.3bn (2016 USD). Berry et al. (1999) point out that "The forgone revenue with a VER is sometimes referred to as the bribe paid in order to induce Japan to agree to the policy in the first place. Our (precise) estimates suggest this was a hefty bribe."

The Berry et al. (1999) evidence on the magnitudes of profit shifting caused by the VER are somewhat dependent on the model and the econometric estimates. Additional evidence is obtained by Ries (1993) using an event study approach. Ries finds that the stock market evaluation of Japanese car makers rose by $42 \%$ during the 19 -week window of VER news analyzed in his study. Stock prices also rose for larger and more specialized parts makers. The total value shifted to the Japanese firms in the auto industry is estimated to be as much as $\$ 6.6$ billion, which is of the same order of magnitude as that found in the structural estimation approach, which is both remarkable and reassuring given the vast differences in data and methodology.

Levinsohn (1997) applies the methodology of Berry et al.(1995) to a lesser known case of trade barriers that the US briefly imposed on the Japanese in 1995. In a bit of brinkmanship to coerce the Japanese into importing more auto parts from the United States, President Clinton announced $100 \%$ tariffs on 13 Japanese luxury cars. The probable rationale was that these were profitable models that the Japanese makers assembled in Japan (not in their US plants). Levinsohn estimates that the effect of these tariffs would be to lower aggregate Japanese profits by $12.5 \%$, a large number when considering that none of the 13 models was a big seller. The Japanese capitulated 
and agreed to a pact in which they would increase purchases of US parts by about $50 \%$. The US then dropped the tariffs just six weeks after they had been imposed.

It is hard to even understand the motivations of the US and Japanese government without a framework that involves considerable producer surplus, in the form of profits and/or worker quasi-rents. Levinsohn (1997) showed that by targeting high markup cars (he estimates the Lerner markup to vary from 31 to $39 \%$ ), a sizeable reduction in profits could be achieved from narrowly targeted tariffs. He also finds that the estimated cross price elasticities implied that most of the benefits of the policy would accrue to European makers in the form of a $15 \%$ profit increase.

The point we want to make is not that governments should rush to implement strategic trade policy. Rather, our point is that quantitative models should not assume that the profit changes caused by trade policies are small enough to disregard. In addition to being important components in an overall assessment of welfare effects, profit (and labour rent) changes are likely to be particularly important for understanding the political economy of trade policy.

\subsection{Is monopolistic competition better at handling heterogeneous firms?}

As shown in Figure 2, use of monopolistic competition was trending up well before the surge of new research on heterogeneous firms. Among other topics, symmetric firms monopolistic competition models proved useful in understanding home market effects and they provided an early set of foundations for gravity equations. Pioneering empirical work on heterogeneous firms such as Bernard and Jensen (1999) did not impose a theoretical structure. Not surprisingly, an early priority of trade economists was to embed heterogeneous firms in a general equilibrium model. Two rival approaches appear in print in 2003. First Melitz (2003) generalized monopolistic competition to accommodate heterogeneous firms. His model can match the key early empirical finding that exporters tend to be more productive, through the assumption of fixed costs. Second, Bernard et al. (2003), hereafter BEJK, proposed an alternative model featuring a continuum of goods within each of which there is Bertrand competition between undifferentiated firms. The low-cost firm captures the entire market for each good and charges a price equal to the cost of the second most efficient 
firm ${ }^{17}$ This model is also capable of explaining why aggregate trade patterns fit a gravity equation, why exporters are more productive, and why not all firms export to all markets.

The rivalry between the monopolistic competition and Bertrand was short lived. By 2005, Eaton and Kortum had an early version of their paper with Kramarz that employed the monopolistic competition structure. As Eaton et al. (2011) explain in the final version of the paper, "We go with Melitz's (2003) monopolistic competition approach rather than the Ricardian framework with a fixed range of commodities used in BEJK (2003), since it more readily delivers the feature that a larger market attracts more firms, as we see in our French data." In their recent review of the heterogeneous firms literature, Melitz and Redding (2014) work exclusively with monopolistic competition. 18

What made monopolistic competition so appealing for researchers modelling heterogeneous firms? For one thing the constant elasticity of substitution (CES) version of monopolistic competition was already familiar, and easily incorporated into general equilibrium frameworks. With a continuum of firms, aggregation was relatively simple. The Chaney (2008) result that monopolistic competition combines with Pareto-distributed productivity to generate a gravity equation was another big plus, which was further magnified when Arkolakis et al. (2012) demonstrated that this would allow it to share the same gains from trade formula as other derivations of the gravity equation. These advantages of monopolistic competition are very likely the most important reason why this market structure came to dominate oligopoly until recently.

The CES demand structure simplifies analysis and estimation of monopolistic competition with heterogeneous firms, but one undesirable implication is that markups are constant across firms in contradiction with many empirical micro-level studies..$^{19}$ Relaxing the CES assumption to allow for more general utility functions under monopolistic competition restores variable markups. In recent

\footnotetext{
${ }^{17}$ This contestable market structure rules out strategic interactions between firms with respect to the choice of price.

${ }^{18}$ In a different chapter in the same Handbook, Costinot and Rodriguez-Clare (2013) suggested that departing from monopolistic competition would be "potentially fruitful" but they note that the BEJK form of Bertrand competition does not change any of the predictions from the monopolistic competition models.

${ }^{19}$ For example, Amiti et al. (2016) uses Belgium micro-level data to show the importance of strategic complementarity in pricing: firms raise their prices (and margins) significantly in response to a price rise by competitors even though their marginal costs are unchanged.
} 
years researchers have experimented with a dizzying array of non-CES preferences. Arkolakis et al. (ming) devise a general form that nests almost all of these preference variants. Combined with Pareto-distributed productivity, these variable-markup monopolistic competition models still generate gravity equations for bilateral trade. As a consequence, Arkolakis et al. (ming) are able to generalize the Arkolakis et al. (2012) welfare formula to allow for variable markups. Somewhat surprisingly the effects of trade liberalization on markups lead to slightly lower gains from trade. Although domestic markups are reduced due to what is referred to as the "pro-competitive effects of trade liberalization," foreign markups increase with the net result that there is small increase in markups on average.

In "Monopolistic competition without apology" Thisse and Ushchev (2018) offer a more general line of defense for monopolistic competition. They emphasize that it is a market structure in its own right and that it is more general than the special CES demand framework. They envision monopolistic competition as a tractable simplification of oligopoly. As they put it,

[G]eneral models of monopolistic competition are able to mimic oligopolistic markets with free entry within a general equilibrium framework." (italics added)

The limiting behaviour of Bertrand and Cournot oligopoly under a broad class of utility functions is shown to resemble monopolistic competition as the number of firms is increased indefinitely. This is a useful insight, but as we have previously mentioned, such limiting behaviour is not inevitable due to the "integer problem" when fixed costs of entry are large enough relative to the size of the market. Then strategic interactions, and in particular profit-shifting motives, remain important. Love of variety is important for the convergence to monopolistic competition. As Thisse and Ushchev demonstrate, there are classes of demand functions incorporating relatively little love of variety under which oligopoly models converge to pure competition. The idea of monopolistic competition as a tractable simplification of oligopoly is appealing, but by definition the model is still unable to incorporate the empirical reality of massive firms.

One of the key assumptions that has made monopolistic competition so useful is that it combines well with the Pareto distribution for productivity—as Arkolakis et al. (ming) demonstrate so 
persuasively. This assumption has been called into question by Combes et al. (2012) and Head et al. (2014). The log-normal distribution provides a better approximation for the complete distribution of productivities and export sales than does Pareto. Without Pareto, heterogeneous firm models no longer yield the gravity equation for aggregated trade flows. Deprived of Pareto's assistance, monopolistic competition loses one of its key advantages over oligopoly models ${ }^{20}$

It is tempting to argue that the indisputable fact of firms as large as countries is adequate justification for explicitly considering massive firms. However, economic theory is accustomed to making assumptions about agents in a model that are admittedly counterfactual so long as the agents behave as if the assumption were true. Based on this argument, there is no compelling reason to abandon massless firms in models if the large firms in the data behave indistinguishably from the monopolistic competition predictions. Even so, to the extent that researchers move away from CES utility and Pareto distribution assumptions making oligopoly models no more intractable than monopolistic competition, it become reasonable to ask: Why not use a more realistic model that handles large firms when the model provides the same predictions and, in some cases, more accurate predictions that better capture the observable facts?

\section{The return of the few}

In 2003, the same year the publication of Melitz (2003) put monopolistic competition on a path to dominance in the trade literature, Peter Neary (2003) spoke out in favour of renewed use of oligopoly models. His Presidential Address to the European Economic Association began by pointing out the "pitfalls on the road to general oligopolistic equilibrium." On the one hand, the modeller wants firms to be large enough to act strategically within their industry. But one does not want them to be so large as to take wages and consumer incomes as endogenous variables in the maximization problem. The resolution of this dilemma would have to involve frameworks in which firms are "large in the small and small in the large." This could be achieved elegantly via a

\footnotetext{
${ }^{20}$ Arkolakis et al. (ming) graph simulations showing that gains from trade liberalization do not deviate dramatically when they replace the Pareto assumption with a log-normal productivity distribution.
} 
continuum of sectors inside of which operate granular firms. ${ }^{21}$

Empirical work in the following years made the role of large firms in trade increasingly hard to ignore. Whether the firm size distribution is Pareto or not, there is no denying it has a very thick right tail. The biggest firms are very big indeed, a fact that combines poorly with the assumption that all firms are massless. Bernard et al. (2007) and Mayer and Ottaviano (2007) established that relatively small numbers of multi-product multi-market firms account for the lion's share of total exports. In the US only $12 \%$ of firms export five or more products to five or more destinations but they collectively exported $92 \%$ of the US total in 2000 . French exports are similarly concentrated, with the $11 \%$ of French firms who export five or more products to five or more countries accounting for $87 \%$ of the 2003 total.

Armed with the new facts on large firm contributions, Neary (2010) renewed his call for oligopoly models to return to centre stage. His paper, "Two and a half theories of trade," begins with the premise that international trade theory has fully developed models of trade under perfect competition and monopolistic competition but only elements of a model for oligopoly. Neary then sketches out an agenda for models that remove the assumption of massless firms:

[]A]part from embedding oligopoly in general equilibrium, endogenising entry and exit while retaining a role for large firms that compete strategically is I believe the key to developing oligopolistic models which can throw light on the nature of competition in todays globalised world.

One idea in Neary (2010) we find particularly promising is the "market-size elasticity of market structure," defined as "the proportional rise in the equilibrium number of firms in response to a proportional increase in market size." Neary argues that the elasticity need not be positive over all ranges of market size. The number of entrants can fall with market size if the incumbents have the ability to make what Neary calls "unfriendly" investment. For example, R\&D investments can make the industry less attractive to potential entrants. The inclusion of an R\&D stage prior

\footnotetext{
${ }^{21} \mathrm{~A}$ drawback of this continuum approach is that it rules out the monopsony implications of market concentration emphasized by the Council of Economic Advisers (2016b) .
} 
to product market competition harkens back to the game of Brander and Spencer (1983). Putting oligopoly back in trade models may be especially fruitful in combination with firm investment decisions 22

In the remainder of this section we spotlight some recent papers that take up the Neary challenge of reinstating oligopoly as a crucial element of trade models. The first line of papers builds on the 2003 BEJK model. Two papers investigate how trade liberalization affects markups in this winner-take-all version of Bertrand oligopoly. De Blas and Russ (2015) point out that in the BEJK model, domestic markups remain constant despite greater foreign competition. They show that if the assumed Pareto distribution for firm productivities is replaced with a Frechét distribution and only a finite number of potential entrants compete for each product, then expected markups decline with the number of foreign rivals in accordance with empirical findings. Holmes et al. (2014) also relax the assumption of a Pareto distribution, but assume that productivity is log-normal. A main contribution is to develop an index of allocative efficiency arising from variation in markups. Holding prices fixed, trade liberalization tends to increase allocative efficiency in symmetric countries because average markups across countries become more similar.

BEJK makes the extreme assumption that all potential entrants in each sector produce identical products. Atkeson and Burstein (2008) relax that assumption to allow for product differentiation within sectors. In their influential model, inputs are produced under quantity competition by a finite number of differentiated domestic and foreign firms in a continuum of sectors. Each country produces a non-traded final good under perfect competition by combining the inputs based on a upper-level CES production function. ${ }^{23}$ Each firm recognizes that it can affect aggregate sectoral prices and output, but tractability is enhanced since no firm can affect the final-good price or wages due to the continuum of sectors. Markups increase smoothly with market share so long as the elasticity of demand across sectors is lower than the within-sector elasticity. The model explains both imperfect pass-through and pricing-to-market, phenomena that are well-documented in the

\footnotetext{
${ }^{22}$ In that vein, Brander and Spencer (2015) allow a domestic and foreign firm under Cournot or Bertrand competition to invest in differentiating their products from each other. These investments magnify the gains from trade.

${ }^{23} \mathrm{As}$ is the main case considered by Holmes et al. (2014), productivity is assumed to be log-normal.
} 
empirical literature, but inconsistent with CES monopolistic competition. In their quantitative exercises, Atkeson and Burstein (2008) find that variable markups within sectors are the "critical feature of market structure in generating quantitatively significant pricing-to-market."

Eaton et al. (2013) study the impact of dropping the continuum of firms assumption which is a standard component of the modern monopolistic competition approach. Their main results utilize Bertrand pricing following Atkeson and Burstein (2008). They find that the markup charged by the largest firm has 5-95 percentile range of 1.25 to 1.29 under parameter settings in which the monopolistic competition markup would be 1.22 . The lower ranked firms charge only "negligibly higher" markups than 1.22. However, a footnote reveals that the Bertrand competition assumption may matter considerably for the quantitative results. With Cournot competition, the markups of the top firm can range to 1.45 and the second firm can charge a markup of 1.3 .

Edmond et al. (2015) also apply the Atkeson-Burstein approach to explore gains from trade in a quantitative model. They find important pro-competitive effects: opening up to trade substantially reduces markup distortions. But the choice of Cournot versus Bertrand competition makes much less difference to average markups and gains from trade than was the case in Eaton et al. (2013). The pro-competitive effects are only slightly larger under Bertrand than their Cournot benchmark.

Two recent papers employ oligopoly as a tool in models whose main focus is the determination of comparative advantage. Gaubert and Itskhoki (2016) investigate the role of granular firms using the Atkeson and Burstein (2008) framework so that firms can be massive within their sectors. Although the continuum of sectors assumption prevents the general equilibrium problems described by Neary (2003), big firms still manage to shape a country's pattern of comparative advantage. Sutton and Trefler (2016) observe that for $73 \%$ of the trade they study that the "richest significant exporter is at least 55 times richer than its poorest significant exporter." Their model assumes Cournot competition between vertically differentiated firms as a device to allow firms from different countries, with differing levels of quality, to coexist in equilibrium. They argue that monopolistic competition is not consistent with the dominance of a few large firms and does not support the coexistence of goods exhibiting vertical differences in quality. Sutton and Trefler 
consider a development process in which countries exogenously increase their ability to produce high quality goods. In equilibrium this leads to a hill-shaped relationship between market shares and per capita incomes that conforms with what Sutton and Trefler find in the data.

Hottman et al. (2016), hereafter HRW, emphasize that when thinking about large oligopolistic firms, it is essential to model them as producers of multiple imperfectly substitutable varieties. They use scanner data so the concept of varieties is the universal product code (UPC or "barcode"). Over two thirds of firms supply multiple UPCs and such firms account for more than $99 \%$ of the production in their respective sectors. Not only are multi-product firms important within their sectors, they often operate across multiple sectors. To keep their main model tractable, HRW deviate from Atkeson and Burstein (2008) by making the upper tier continuum of sectors have an elasticity of substitution given by one (Cobb-Douglas). This makes pricing in each sector independent from other sectors (as well as general equilibrium issues). HRW estimate a nested CES, finding a median elasticity of substitution of 7 between barcodes and 4 between firms.

The results of HRW point towards a hybrid model of market structure:

[T]he typical sector comprises a few large firms with substantial market shares and a competitive fringe of firms with trivial market shares. Therefore most firms charge markups close to the monopolistic competition benchmark... [T] he median largest firm charges a markup between $24 \%$ and $100 \%$ higher than the average firm within the same sector.

On the basis of counterfactual simulations, HRW show that moving from Bertrand to monopolistic competition reduces the consumer price index by around $4 \%$, a non-trivial gain, but a move from Cournot lowers the CPI by a whopping $13 \%$. The magnitudes of these numbers make it clear that oligopoly matters for welfare. For a large closed country, consumer gains from eliminating oligopoly could rival or surpass the gains from trade.

Two recent theory papers show how the presence of oligopoly interacts in important ways with trade liberalization, in the realistic case of market structures that are hybrids of oligopoly and monopolistic competition. In Shimomura and Thisse (2012) the market contains an exogenous 
number $N$ of massive firms coexisting with a measure $M$ of massless monopolistically competitive firms. $M$ is determined by free-entry. The paper focuses on the impact of entry by large firms in a closed economy but the authors make two remarks in the conclusion on the impact of trade cost reductions. "[B]y exacerbating competition between large firms, economic integration triggers the progressive disappearance of small firms." One intriguing implication is that the exit of small firms would be a good thing for aggregate productivity in the realistic case that the large firms are lower cost producers.

Parenti (2016) in an evocatively sub-titled paper, "David vs Goliath," advances the approach of combining massive and massless firms in the same industry. In contrast to Shimomura and Thisse (2012), Parenti's model endogenizes the scope of the large firms by having them decide on how many products to offer. The key finding is that large firms respond to trade liberalization by expanding at the expense of exiting small firms. Overall variety expands (because of the widening scope of the big firms) and so do profits, but consumer surplus may decline. This scenario is consistent with the facts of increasing concentration and rising profits presented in section 4.1 .

Having brought oligopoly out of the cold and back into international trade, the obvious next step is to bring it back into models of multinational corporations (MNCs). Only the strong attraction of tractability can justify treating huge MNCs as part of a continuum of massless firms. Coşar et al. (2016) implement at the industry level an estimation of an oligopoly model of multinational car makers. They use the random coefficients demand structure introduced by Berry et al. (1995). Bernard et al. (2016) build on the product market structure of Hottman et al. (2016), augmenting it with a rich set of supply-side decisions from the global sourcing and multinational production literatures. They develop an encompassing model of large, globalized firms, who extend on multiple margins in concert. Oligopoly is not so much the focus of the paper as it is a necessary accommodation of the real world fact of massive, global firms. 


\section{Conclusion}

The incorporation of oligopoly market structures into international trade models in the early 1980s led to a productive stream of research that thrived well into the 1990s. In the 2000s, monopolistic competition became the dominant modelling structure, in part because it combined nicely with firm heterogeneity. We have critiqued many of the reasons that have been offered for moving away from oligopoly. Citing recent work and showing new evidence, we argue that oligopoly has increasing relevance for both international trade and the distribution of income. Renewed use of the oligopoly assumption was clearly warranted as soon as researchers could resolve the technical challenges of tractably incorporating heterogeneous firms in a quantitative general equilibrium framework. Following important progress on these lines in the last decade, the tool-kit of international trade research is able to handle industries that feature a small number of massive firms.

Comparing the original series of oligopoly and trade papers to the next generation, the differences stand out more than the similarities. Functional forms have changed, with the new quantitative papers working mainly with nested CES, whereas the older work tended to use general demand when possible, and linear when not. The number, complexity, and heterogeneity of the firms in the new models have all increased. Another contrast is the emphasis on general equilibrium in the more recent work. Finally, the end uses of the first and latest generation models have been very different so far. Recent papers have investigated positive issues, such as pass-through and zero trade flows, with some attention to the overall gains from trade. In contrast, the older literature focused on trade policies such as subsidies and tariffs. At least one issue has crossed over from the 1980s literature. The distinction between Cournot and Bertrand oligopoly sometimes—but not always - strongly affects the results. The continued relevance of this issue motivates more effort to discriminate empirically between these classic alternatives.

Going forward, we hope to see a renewed focus on quantifying the impact of trade and traderelated policies in oligopoly settings where profit shifting could be of first-order importance. Two Canadian examples come to mind. First, Canada and Ontario have a history of large subsidies to automobile firms, aimed at maintaining production in Ontario. The industry also faces open 
questions of how it would fare if the US were to withdraw from NAFTA. Working through subsidy or trade policy counterfactuals requires careful consideration of the ultimate owners of these firms to ascertain whom would be affected by resulting changes in profits. Moreover, quantification of policy should consider the impacts on unionized workers since they likely capture some of the oligopoly rent in the form of above-normal wages. A final example emerged as we composed this conclusion. Bombardier's market value fell 5\% on the April 27 announcement that Boeing had petitioned the US government to impose anti-dumping duties on its regional jets. Earlier in 2017, the Brazilian government complained at the World Trade Organization that the \$372.5-million cash injection Bombardier had just received from the federal government was an illegal subsidy. We can only make sense of these policy interactions and stock market responses in a model of where oligopoly profits stand to be shifted between countries by policy tools.

Oligopoly models open up research opportunities in the international context that go beyond tariffs and subsidies. Competition policies such as cross-border merger approval (e.g. AB-InBev) and the abuse of dominant position by a foreign firm (e.g. Google in the European Union) differ from domestic cases because they involve international profit-shifting. Similarly, the strength of intellectual property regulation affects the competitive positions of foreign multinationals. Finally, in the presence of oligopoly, plant locations depend on more than costs and demand-the reactions of rivals become a primary consideration. While prior work has investigated each of these issues, the new nested CES oligopoly framework should facilitate more quantitative approaches.

\section{References}

Amiti, M., Itskhoki, O., and Konings, J. (2016). International shocks and domestic prices: how large are strategic complementarities? Working Paper 22119, National Bureau of Economic Research.

Arkolakis, C., Costinot, A., Donaldson, D., and Rodríguez-Clare, A. (forthcoming). The elusive pro-competitive effects of trade. The Review of Economic Studies.

Arkolakis, C., Costinot, A., and Rodriguez-Clare, A. (2012). New trade models, same old gains? American Economic Review, 102(1):94-130. 
Atkeson, A. and Burstein, A. (2008). Pricing-to-market, trade costs, and international relative prices. The American Economic Review, 98(5):1998-2031.

Auquier, A. A. and Caves, R. E. (1979). Monopolistic export industries, trade taxes, and optimal competition policy. The Economic Journal, pages 559-581.

Autor, D., Dorn, D., Katz, L. F., Patterson, C., and Van Reenen, J. (2017a). Concentrating on the fall of the labor share. American Economic Review, 107(5):180-85.

Autor, D., Dorn, D., Katz, L. F., Patterson, C., and Van Reenen, J. (2017b). The fall of the labor share and the rise of superstar firms. Working Paper 23396, National Bureau of Economic Research.

Bagwell, K. and Staiger, R. W. (1994). The sensitivity of strategic and corrective R\&D policy in oligopolistic industries. Journal of International Economics, 36(1-2):133-150.

Baldwin, R. E. and Richardson, J. D. (1987). Recent u.s. trade policy and its global implications. In Bradford, J. C. I. and Branson, W. H., editors, NBER Volume- Trade and Structural Change in Pacific Asia, pages 121-156. University of Chicago Press.

Barkai, S. (2016). Declining labor and capital shares. Stigler Center Working Paper 2, University of Chicago.

Ben-Zvi, S. and Helpman, E. (1992). Oligopoly in segmented markets. In Grossman, G. M., editor, Imperfect competition and international trade, pages 31-53. MIT Press.

Bernard, A. B., Eaton, J., Jensen, J. B., and Kortum, S. (2003). Plants and productivity in international trade. The American Economic Review, 93(4):1268-1290.

Bernard, A. B. and Jensen, J. B. (1999). Exceptional exporter performance: cause, effect, or both? Journal of International Economics, 47(1):1-25.

Bernard, A. B., Jensen, J. B., Redding, S. J., and Schott, P. K. (2007). Firms in international trade. Journal of Economic Perspectives, 21(3):105-130.

Bernard, A. B., Jensen, J. B., Redding, S. J., and Schott, P. K. (2016). Global firms. Working Paper 22727, National Bureau of Economic Research.

Berry, S., Levinsohn, J., and Pakes, A. (1995). Automobile prices in market equilibrium. Econometrica, pages 841-890.

Berry, S., Levinsohn, J., and Pakes, A. (1999). Voluntary export restraints on automobiles: evaluating a trade policy. American Economic Review, 89(3):400-430.

Brander, J. A. (1981). Intra-industry trade in identical commodities. Journal of International Economics, 11(1):1-14.

Brander, J. A. (1995). Strategic trade policy. Handbook of International Economics, 3:1395-1455. 
Brander, J. A. and Krugman, P. R. (1983). A 'reciprocal dumping' model of international trade. Journal of International Economics, 15(3):313-321.

Brander, J. A. and Spencer, B. J. (1981). Tariffs and the extraction of foreign monopoly rents under potential entry. Canadian Journal of Economics, pages 371-389.

Brander, J. A. and Spencer, B. J. (1983). Strategic commitment with R\&D: the symmetric case. The Bell Journal of Economics, pages 225-235.

Brander, J. A. and Spencer, B. J. (1984a). Tariff protection and imperfect competition. In Kierzkowski, H., editor, Monopolistic competition and international trade, pages 194-206. Clarendon Press - Oxford.

Brander, J. A. and Spencer, B. J. (1984b). Trade warfare: tariffs and cartels. Journal of International Economics, 16(3):227-242.

Brander, J. A. and Spencer, B. J. (1985). Export subsidies and international market share rivalry. Journal of International Economics, 18(1):83-100.

Brander, J. A. and Spencer, B. J. (2015). Intra-industry trade with Bertrand and Cournot oligopoly: The role of endogenous horizontal product differentiation. Research in Economics, 69(2):157165.

Burstein, A. T., Neves, J. C., and Rebelo, S. (2003"). Distribution costs and real exchange rate dynamics during exchange-rate-based stabilizations. Journal of Monetary Economics, 50(6):1189 $-1214$.

Caves, R. E. (1974). International trade, international investment, and imperfect markets. Number 10 in Special Papers in International Economics. International Finance Section, Princeton University.

Chaney, T. (2008). Distorted gravity: The intensive and extensive margins of international trade. American Economic Review, 98(4):1707-21.

Cheng, L. K. (1988). Assisting domestic industries under international oligopoly: The relevance of the nature of competition to optimal policies. The American economic review, pages 746-758.

Clarke, R. and Collie, D. R. (2006). Optimum-welfare and maximum-revenue tariffs under Bertrand duopoly. Scottish Journal of Political Economy, 53(3):398-408.

Coşar, K., Grieco, P., Li, S., and Tintelnot, F. (2016). Taste heterogeneity, trade costs, and global market outcomes in the automobile industry. mimeo.

Collie, D. R. (1998). Trade policy under Bertrand duopoly with integrated markets: the pure strategy equilibrium. Economics Letters, 60(2):179-183.

Collie, D. R., Hviid, M., and Kendall, T. (1999). Strategic trade policy under integrated markets. Journal of Economic Integration, pages 522-553. 
Combes, P.-P., Duranton, G., Gobillon, L., Puga, D., and Roux, S. (2012). The productivity advantages of large cities: Distinguishing agglomeration from firm selection. Econometrica, 80(6):2543-2594.

Costinot, A. and Rodriguez-Clare, A. (2013). Trade theory with numbers: Quantifying the consequences of globalization. In Helpman, E., editor, Handbook of International Economics, volume 4. Elsevier.

Council of Economic Advisers (2016a). The 2016 Economic Report of the President, chapter 1, Inclusive growth in the United States, pages 21-49. Government Publishing Office (US).

Council of Economic Advisers (2016b). Labor market monopsony: Trends, consequences, and policy responses. Issue Brief.

Cox, D. and Harris, R. (1985). Trade liberalization and industrial organization: Some estimates for canada. Journal of Political Economy, 93(1):115-145.

De Blas, B. and Russ, K. N. (2015). Understanding markups in the open economy. American Economic Journal: Macroeconomics, 7(2):157-180.

Dixit, A. (1979). Quality and quantity competition. The Review of Economic Studies, 46(4):587599.

Dixit, A. (1984). International trade policy for oligopolistic industries. The Economic Journal, 94:1-16.

Dixit, A. K. and Grossman, G. M. (1986). Targeted export promotion with several oligopolistic industries. Journal of International Economics, 21(3-4):233-249.

Eaton, J. and Grossman, G. M. (1986). Optimal trade and industrial policy under oligopoly. The Quarterly Journal of Economics, 101(2):383-406.

Eaton, J., Kortum, S., and Kramarz, F. (2011). An anatomy of international trade: Evidence from French firms. Econometrica, 79(5):1453-1498.

Eaton, J., Kortum, S., and Sotelo, S. (2013). International trade: Linking micro and macro. In Advances in Economics and Econometrics: Tenth World Congress, volume 2, page 329. Cambridge University Press.

Edmond, C., Midrigan, V., and Xu, D. Y. (2015). Competition, markups, and the gains from international trade. The American Economic Review, 105(10):3183-3221.

Feenstra, R. C. (1995). Estimating the effects of trade policy. Handbook of International Economics, 3:1553-1595.

Freund, C. and Pierola, M. D. (2015). Export superstars. Review of Economics and Statistics, 97(5):1023-1032.

Gaubert, C. and Itskhoki, O. (2016). Granular comparative advantage. UC Berkeley, mimeo. 
Harris, R. G. (1989). The new protectionism revisited. Canadian Journal of Economics, 22(4):751-778.

Head, K., Mayer, T., and Thoenig, M. (2014). Welfare and trade without Pareto. American Economic Review, 104(5):310-16.

Head, K. and Ries, J. (1999). Rationalization effects of tariff reductions. Journal of International Economics, 47(2):295-320.

Helpman, E. and Krugman, P. R. (1989). Trade policy and market structure. MIT press.

Holmes, T. J., Hsu, W.-T., and Lee, S. (2014). Allocative efficiency, mark-ups, and the welfare gains from trade. Journal of International Economics, 94(2):195-206.

Horstmann, I. J. and Markusen, J. R. (1986). Up the average cost curve: Inefficient entry and the new protectionism. Journal of International Economics, 20(3-4):225-247.

Hottman, C. J., Redding, S. J., and Weinstein, D. E. (2016). Quantifying the sources of firm heterogeneity. The Quarterly Journal of Economics, 131(3):1291-1364.

Hufbauer, G. C. and Erb, J. S. (1984). Subsidies in International Trade. MIT Press.

Irwin, D. A. (1991). Mercantilism as strategic trade policy: the Anglo-Dutch rivalry for the East India trade. Journal of Political economy, 99(6):1296-1314.

Katrak, H. (1977). Multi-national monopolies and commercial policy. Oxford Economic Papers, 29(2):283-291.

Kreps, D. M. and Scheinkman, J. A. (1983). Quantity precommitment and bertrand competition yield cournot outcomes. The Bell Journal of Economics, 14(2):326-337.

Krugman, P. R. (1984). Import protection as export promotion: International competition in the presence of oligopoly and economies of scale. In Kierzkowski, H., editor, Monopolistic competition and international trade, pages 180-93. Clarendon Press - Oxford.

Krugman, P. R. (1989). Industrial organization and international trade. In Handbook of Industrial Organization, volume 2, pages 1179-1223. Elsevier.

Leahy, D. and Neary, P. (2015). When the threat is stronger than the execution: Trade liberalization and welfare under oligopoly. Discussion Paper 775, University of Oxford.

Levinsohn, J. (1997). Carwars: Trying to make sense of US-Japan trade frictions in the automobile and automobile parts markets. In The Effects of US Trade Protection and Promotion Policies, pages 11-32. University of Chicago Press.

Maggi, G. (1996). Strategic trade policies with endogenous mode of competition. The American Economic Review, 86(1):237-258.

Markusen, J. R. (1981). Trade and the gains from trade with imperfect competition. Journal of International Economics, 11(4):531-551. 
Markusen, J. R. and Venables, A. J. (1988). Trade policy with increasing returns and imperfect competition: Contradictory results from competing assumptions. Journal of International Economics, 24(3-4):299-316.

Mayer, T. and Ottaviano, G. (2007). The Happy Few: The Internationalisation of European firms. Bruegel Blueprint Series.

Melitz, M. J. (2003). The impact of trade on intra-industry reallocations and aggregate industry productivity. Econometrica, 71(6):1695-1725.

Melitz, M. J. and Redding, S. J. (2014). Heterogeneous firms and trade. In Helpman, E., Gopinath, G., and Rogoff, K., editors, Handbook of International Economics, volume 4. Elsevier.

Melvin, J. and Warne, R. D. (1973). Monopoly and the theory of international trade. Journal of International Economics, 3(2):117-134.

Nasar, S. (1985). The new case for protectionism. Fortune, pages 33-38.

Neary, J. P. (2003). Presidential address: Globalization and market structure. Journal of the European Economic Association, 1(2/3):245-271.

Neary, J. P. (2010). Two and a half theories of trade. The World Economy, 33(1):1-19.

Parenti, M. (2016). Large and small firms in a global market: David vs. Goliath. Manuscript, Université Libre de Bruxelles.

Richardson, J. D. (1989). Empirical research on trade liberalization with imperfect competition: A survey. OECD Economic Studies, 12.

Ries, J. C. (1993). Windfall profits and vertical relationships: Who gained in the japanese auto industry from vers? The Journal of Industrial Economics, 41(3):259-276.

Ross, T. W. (1988). Movements towards free trade and domestic market performance with imperfect competition. Canadian Journal of Economics, pages 507-524.

Shepherd, W. G. (1982). Causes of increased competition in the U.S. economy, 1939-1980. The Review of Economics and Statistics, 64(4):613-626.

Shimomura, K.-I. and Thisse, J.-F. (2012). Competition among the big and the small. The Rand Journal of Economics, 43(2):329-347.

Spencer, B. J. (1986). What should trade policy target? In Krugman, P. R., editor, Strategic trade policy and the new international economics, pages 71-80. MIT Press Cambridge, MA.

Spencer, B. J. and Brander, J. A. (1983). International R\&D rivalry and industrial strategy. The Review of Economic Studies, 50(4):707-722.

Stegemann, K. (1989). Policy rivalry among industrial states: what can we learn from models of strategic trade policy? International Organization, 43(01):73-100. 
Sutton, J. and Trefler, D. (2016). Capabilities, wealth, and trade. Journal of Political Economy, 124(3):826-878.

Thisse, J.-F. and Ushchev, P. (2018). Monopolistic competition without apology. In Corchón, L. and Marini, M., editors, Handbook of Game Theory and Industrial Organization, volume 1. Edward Elgar.

Venables, A. (1994). Trade policy under imperfect competition: a numerical assessment. In Krugman, P. R. and Smith, A., editors, Empirical studies of strategic trade policy, pages 41-66. University of Chicago Press.

Venables, A. J. (1985). Trade and trade policy with imperfect competition: The case of identical products and free entry. Journal of International Economics, 19(1):1-19.

Venables, A. J. (1990). International capacity choice and national market games. Journal of International Economics, 29(1-2):23-42. 